\title{
E-Learning Acceptance: The Role of Task-Technology Fit as Sustainability in Higher Education
}

\author{
Ibrahim Youssef Alyoussef
}

Faculty of Education, Education Technology Department, King Faisal University, Al Ahsa 31982, Saudi Arabia; ialyoussef@kfu.edu.sa

\begin{abstract}
The aim of this study was to fill the gap in the literature on e-learning acceptance and its role in the sustainability of learning and the role of task-technology fit (TTF), which influences student satisfaction and academic performance. While researchers have examined e-learning acceptance in a variety of contexts, the role of TTF as a mediating variable in measuring education sustainability has not been explored using the technology acceptance model (TAM). As a result, the goal of this study was to develop a new paradigm by combining two theories: TFF and the TAM. In total, 432 students and researchers from public universities participated in this study. We surveyed students using the structural equation modelling (SEM) approach to learn about their expectations with regard to e-learning adoption. According to the findings, perceived ease of use has a positive impact on perceived enjoyment and usefulness, which in turn has a positive impact on task-technology fit and e-learning use in higher education, resulting in a positive impact on student satisfaction and academic performance as well as sustainability. Finally, the role of task-technology fit and e-learning usage in education sustainability had a positive effect on student satisfaction and learning performance. As a result, the use of e-learning in learning processes should be encouraged as a long-term strategy in higher education institutions.
\end{abstract}

Citation: Alyoussef, I.Y. E-Learning Acceptance: The Role of

Task-Technology Fit as Sustainability in Higher Education. Sustainability 2021, 13, 6450. https://doi.org/ $10.3390 /$ su13116450

Academic Editors: Waleed Mugahed Al-Rahmi and Qusay Al-Maatouk

Received: 3 May 2021

Accepted: 30 May 2021

Published: 6 June 2021

Publisher's Note: MDPI stays neutral with regard to jurisdictional claims in published maps and institutional affiliations.

Keywords: e-learning acceptance; technology acceptance model (TAM); task-technology fit (TTF); sustainability in higher education

\section{Introduction}

e-learning offers many advantages over conventional learning methods, including greater access to learning materials, faster communication, and academic collaboration [1]. The constant advances in technology have made it impossible to develop a unique concept of e-learning. Previous research has attempted to define e-learning in various ways. Several studies [2,3] have defined e-learning as the use of technology in the learning process, while others $[4,5]$ have defined it as an information system that can assimilate a variety of instructional materials through email, discussion, tasks, quizzes, and live chat sessions. The e-learning paradigm is a development of the 1980s distance learning style of education [6]. In the ongoing global lockdown due to the coronavirus disease of 2019 (COVID-19) pandemic, e-learning has proved to be the only choice for ongoing learning [7]. Every university in the world has now invested extensively in e-learning, and many traditional classroom-based classes have changed to e-learning [8,9]. Advancements in digital and communication technology (ICT) have resulted in major improvements in all related areas. To ensure its long-term viability, ICT has embraced emerging paradigms such as cloud computing [10,11], Massive Open Online Courses (MOOCs) [12], the internet of things [13], big data [14,15], e-learning [1], social networking [16,17], and blockchain [18,19]. New platforms, products, systems, and facilities have emerged as a result of these ICT-driven developments [20]. This surge in ICT-driven inventions has also benefited education [10]. ICT has ushered in a slew of emerging learning paradigms, including e-learning and mobile learning [21-23]. Formal, non-formal, and informal learning are all supported by 
e-learning and mobile learning [24]. Previous research [25] has investigated the variables that both threaten and promote the long-term viability of smaller-scale e-learning projects in New Zealand's tertiary sector. In addition, the results provide a detailed overview of emerging e-learning sustainability issues within the industry. The anthology, E-Learning and Curriculum for Sustainability, which includes values, tools, and some good practices from the sector [26], provides a detailed summary and evaluation of these issues. Initially, introducing and executing e-learning in higher education seems to be sustainable. In general, the techniques and approaches used in e-learning are often less intensive than those used in formal education [27]. It was also discovered that implementing online learning leads to sustainability by effectively lowering demand for content and conserving energy [28]. As a result, while early attempts to adopt and use e-learning were rare, the shift in higher education toward e-learning to ensure sustainability has now hit a global scale that can hardly be ignored $[26,29]$. Many recent studies [8,9] have looked at the effectiveness of e-learning programs. Various analytical models, such as the acceptance model [30], information systems success [31], and decomposed theory of planned behavior [32], have been used to research this topic. Many e-learning performance and quality models have been suggested, including e-learning system success $[1,33]$, measuring e-learning system success [2], e-learning quality [34], e-learner satisfaction [8,35], student satisfaction model [36], and student academic performance [37,38]. Similarly, considerations such as usefulness, perceived satisfaction, grade anticipation, advantages, device utilization, adoption, and acceptance have been evaluated [9]. Task-technology fit (TTF), the technology acceptance model (TAM), and social influence have also been studied separately in the past to understand e-learning system use. However, no research has attempted to combine these three models to shape student academic performance in the context of educational sustainability. The investigation of the integration of TTF, the TAM, and social influence on e-learning usage as a sustainable way to influence student academic performance and educational sustainability, is one of this research's main contributions. The results could help managers and academics better understand how the use of e-learning systems affects student academic performance as well as educational sustainability in higher education by bridging the gap between the acceptance and continuation research streams of e-learning system use. In addition, this paper suggests a research paradigm for integrating the technology acceptance model (TAM) for e-learning system use with task-technology fit (TTF) in order to shape student academic success as a means of ensuring educational sustainability.

\section{Theoretical Model and Hypotheses Development}

Davis [39] developed the TAM to explore the relationship between the current application of modern technologies and the intention to use it. The TAM assumes that three main constructs define the individual/organizational knowledge system: perceived usefulness (PU), perceived ease of use (PEOU), and perceived enjoyment (PE). In addition, Goodhue and Thompson [40] suggested the task-technology fit model to emphasize the importance of a good fit between technology and the actual task when it comes to achieving individual performance as a result of technology. Several studies $[40,41]$ have used both contingency and task-technology match theory in the adoption of information systems, implying that the fit between a task and technology is important for information system performance. McGill and Klobas [42] defined task-technology fit as "the degree to which a technology assists a person in executing his or her portfolio of tasks". Thus, in the current research, seven influences on TTF and TAM acceptance of e-learning system usage as sustainability were analyzed as follows: perceived usefulness (PU), perceived ease of use (PEU), perceived enjoyment (PE), social influence (SI), e-learning use as sustainability (MUS), task-technology fit (TTF), student satisfaction (SS), and student academic performance (SAP), see Figure 1. 


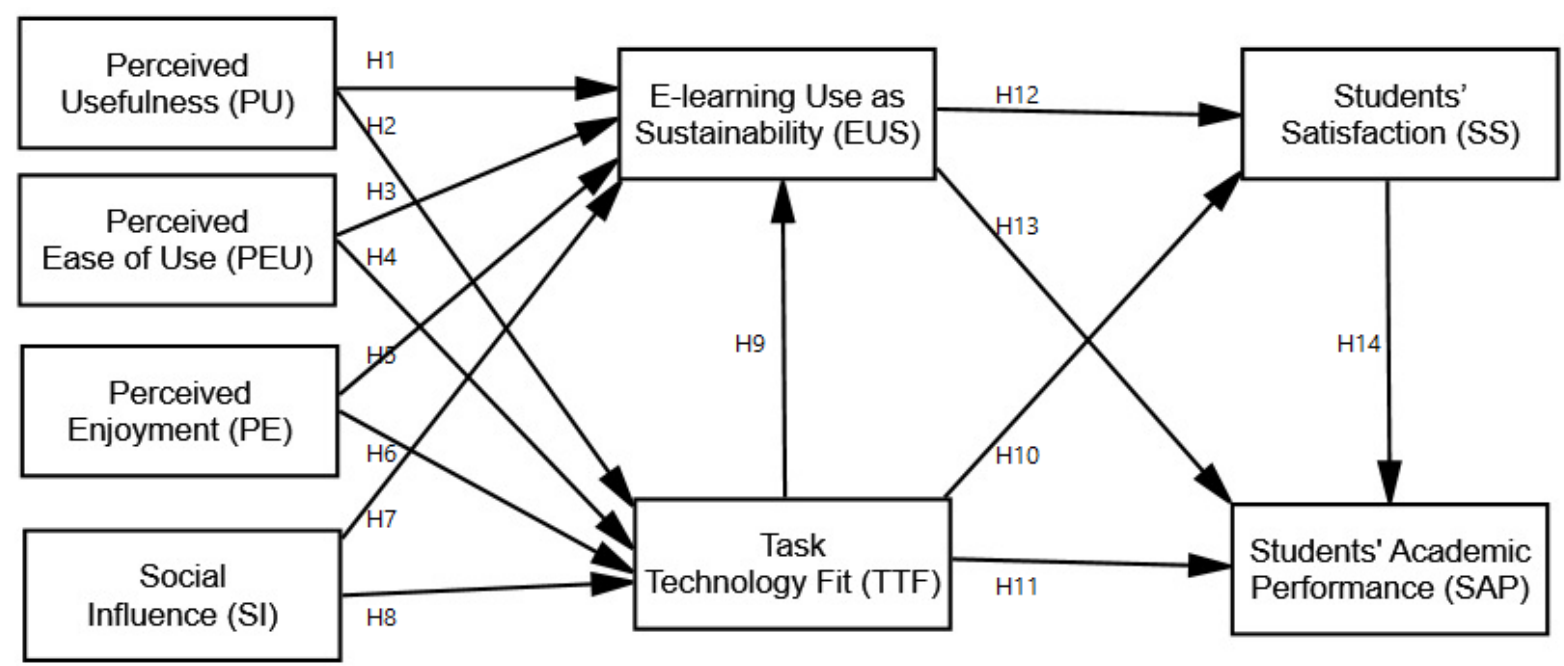

Figure 1. Research model and hypotheses.

\subsection{Perceived Usefulness (PU)}

The TAM model is used to examine e-learning systems, and perceived usefulness and ease of use are called independent constructs [30]. Two factors are identified to measure perceived usefulness: perceived ease of use, perceived enjoyment, and helpfulness in completing the task easily. The perceived usefulness and utilization of an e-learning system were shown to be positively correlated with TTF and actual use of online learning in several studies $[43,44]$.

\subsection{Perceived Ease of Use (PEU)}

Perceived ease of use is a concept that refers to a learner's perception that a system is simple or easy to use $[39,45]$. This concept is used in this analysis to refer to the students' views on how to use this system to improve their learning and performance. Other researchers pointed out that this concept is described in terms of the effort put forth in using a particular system [45-47].

\subsection{Perceived Enjoyment (PE)}

Perceived enjoyment applies to how learners view various activities or programs as fun to them, regardless of any potential implications [48]. Therefore, in the current research, perceived enjoyment is described as learners' enjoyment as a result of using an e-learning system in a way that enriches their learning experiences.

\subsection{Social Influence (SI)}

The degree to which an individual believes important others think he or she can use technology is referred to as social influence [49]. In their analysis comparing universal technological adoption, Im et al. [50] found that social influence played a significant role. According to Yulius et al. [51], an experience cannot improve or degrade social influence relations on e-learning use.

\subsection{E-Learning Use as Sustainability (EUS)}

As a concept, e-learning encompasses a wide variety of applications, learning techniques, and processes [52]. In this approach to using e-learning, Algahtani [53] and Zeitoun [54] demonstrated that the distribution of course materials and descriptions is shared between conventional and e-learning methods in the classroom environment. The use of information and communication technology to allow access to online learning/teaching services is referred to as e-learning. Abbad et al. [55] and Al-rahmi et al. [1] described e-learning as "any learning that is allowed electronically" in its broadest sense. 
They might, however, limit this concept to learning that is facilitated by the use of digital technologies. This technology-assisted e-learning paradigm has created a widespread environment for learning at any time and from any place, promoting the cause of intergenerational schooling for long-term sustainability [56]. In the ongoing global lockdown due to the COVID-19 pandemic, e-learning has proved to be the only choice for replacing traditional face-to-face learning methods. Academic universities all over the world have made substantial improvements in e-learning, and the bulk of conventional lecture classes have been migrated to e-learning. The success of e-learning programs must be assured in order for it to become sustainable for learning [9].

\subsection{Task-Technology Fit (TTF)}

The TTF model is based on the need for a correlation between technology characteristics and task specifications [57]. According to the model, focusing solely on students' expectations of technology is insufficient to estimate its adoption. Students will accept technology if they believe it is effective enough to perform their everyday activities [40]. This theory's paradigm sheds light on the functional aspects of technology use. Since focusing solely on customer expectations of technology is insufficient, the task-technology fit (TTF) model predicts when users will use a technology based on a correlation between performance expectations and technology features [40].

\subsection{Student Satisfaction (SS)}

Wang [58] analyzed adult respondents in a study to learn more about student satisfaction with e-learning, and his results revealed key TAM variables. According to [59], the relationship between the above TAM variables and students' satisfaction with their e-learning use was investigated. As a result, it is useful to look at their effect on TAM variables like student satisfaction and e-learning use and see how they affect academic performance.

\subsection{Student Academic Performance (SAP)}

The ultimate goal of e-learning implementation is to improve learning pedagogy and academic performance $[60,61]$. Other studies have been conducted to assess the progress of e-learning adoption and its effect on student academic performance $[9,62,63]$. The current research will aim to investigate the essence and extent of the relationship between e-learning use as sustainability and student academic performance.

\section{Research Methodology}

The study's key goal was to provide a clear and understandable conceptual model for assessing e-learning acceptance as sustainability and its determinants. The proposed model and questionnaire were conceptualized, validated, and examined using a multistage testing design. To begin, the research was exploratory, with participants testing 25 previously used items to measure student academic performance and extracting eight constructs to determine the acceptability of e-learning as sustainability. Second, the research was empirical, using structural equation modelling (SEM) suggested by [64] for empirically evaluating the proposed conceptual model of e-learning usage as sustainability. In this research data, appropriate statistical tests to validate findings and show significance in the results were used, see Appendix A. The sample size for the review was calculated using Roscoe's rule of thumb in the analysis of [65]. As a result, multiplying 10 by 25 items generated a sample size of 250 participants for this research. The SPSS kit program was then used to import 432 participants. This study's sample includes postgraduate and undergraduate university students who are active users of an e-learning system for sustainability. 


\section{Measurement Methodology}

The scales used to calculate the constructs were adapted and adopted from commonly used validated scales from previous experiments to develop the instruments. Basic demographic management (gender, age, educational level, and specialization) and questionnaire items measuring perceived usefulness, perceived ease of use, perceived enjoyment, and using an e-learning system for sustainability were adapted from the sample questionnaire [39]. Student satisfaction was adapted from [66], task-technology fit was adapted from [67], student academic performance was adapted from [68], and social influence was adapted from [69], see Appendix A.

\section{Analysis and Findings}

The Cronbach's alpha reliability parameter was 0.915 , meaning that the factors that influenced e-learning system use as well as educational sustainability, which in turn affected student academic performance, were reliable. Discriminant validity was assessed using three criteria: variable indices must be less than 0.70 , each construct's average variance extracted (AVE) must be equal to or greater than 0.5, and the AVE square root of each construct must be greater than the inter-construct correlations (IC) for a factor, according to [64]. Aside from the above variables, build factor analysis results with factor loadings of 0.70 or higher (Cronbach's alpha 0.70 and composite reliability 0.70 are acceptable) [64], see Table 1.

Table 1. Cronbach's alpha reliability.

\begin{tabular}{ccc}
\hline Factors & Pilot Test & Final Test \\
\hline Perceived usefulness & 0.702 & 0.843 \\
\hline Perceived ease of use & 0.690 & 0.890 \\
\hline Perceived enjoyment & 0.721 & 0.932 \\
\hline Social influence & 0.821 & 0.873 \\
\hline Task-technology fit & 0.795 & 0.889 \\
\hline Student satisfaction & 0.779 & 0.891 \\
\hline Student academic performance & 0.738 & 0.903 \\
\hline e-learning use as sustainability & 0.778 & 0.911 \\
\hline
\end{tabular}

\subsection{Measurement of Construct Validity}

The degree to which individual objects meet the purpose for which they were developed [70] is referred to as construct validity. This was determined by a thorough examination of previously tested items in the literature. Table 2 shows the items and their loadings that must be loaded into the model they were developed to evaluate [71].

\subsection{Measurement Validity That Is Convergent}

Since the factor loadings of 25 items were greater than 0.70 and their composite reliability was greater than 0.70 , ranging from 0.869 to 0.943 , they were found acceptable. Cronbach's alpha coefficient values ranged from 0.774 to 0.909 , suggesting satisfactory performance. The numbers for AVE ranged from 0.707 to 0.847. Hair et al. [64] mentions the findings of the confirmatory factor analysis (CFA), see Table 3.

\subsection{Measurement Validity That Is Convergent}

Discriminant validity refers to the differences between sets of definitions and their measures. Both constructs' discriminant validity was confirmed with values greater than 0.50 and significant at $p=0.001$, as expected by the study [64]. The AVE square root shared by objects in a single construct should be smaller than the correlations between items in the two constructs [64], as seen in Table 4. 
Table 2. Loadings and cross-loadings of items.

\begin{tabular}{|c|c|c|c|c|c|c|c|c|c|}
\hline Factors & Items & EUS & PE & PEU & PU & SAP & SI & SS & TTF \\
\hline \multirow{3}{*}{ e-learning use as sustainability } & EUS1 & 0.869 & 0.512 & 0.340 & 0.455 & 0.559 & 0.512 & 0.517 & 0.566 \\
\hline & EUS2 & 0.867 & 0.420 & 0.258 & 0.427 & 0.508 & 0.533 & 0.532 & 0.597 \\
\hline & EUS3 & 0.850 & 0.464 & 0.381 & 0.432 & 0.511 & 0.513 & 0.535 & 0.553 \\
\hline \multirow{3}{*}{ Perceived enjoyment } & PE1 & 0.486 & 0.903 & 0.318 & 0.532 & 0.384 & 0.392 & 0.440 & 0.429 \\
\hline & PE2 & 0.516 & 0.932 & 0.347 & 0.563 & 0.431 & 0.430 & 0.433 & 0.441 \\
\hline & PE3 & 0.487 & 0.925 & 0.315 & 0.616 & 0.416 & 0.389 & 0.432 & 0.441 \\
\hline \multirow{3}{*}{ Perceived ease of use } & PEU1 & 0.322 & 0.362 & 0.810 & 0.348 & 0.381 & 0.305 & 0.402 & 0.268 \\
\hline & PEU2 & 0.314 & 0.264 & 0.869 & 0.317 & 0.386 & 0.346 & 0.438 & 0.276 \\
\hline & PEU3 & 0.318 & 0.267 & 0.843 & 0.284 & 0.370 & 0.324 & 0.357 & 0.243 \\
\hline \multirow{3}{*}{ Perceived usefulness } & PU1 & 0.502 & 0.614 & 0.336 & 0.902 & 0.488 & 0.412 & 0.509 & 0.470 \\
\hline & PU2 & 0.424 & 0.592 & 0.290 & 0.891 & 0.453 & 0.404 & 0.519 & 0.434 \\
\hline & PU3 & 0.359 & 0.354 & 0.335 & 0.748 & 0.347 & 0.425 & 0.498 & 0.435 \\
\hline \multirow{3}{*}{ Student academic performance } & SAP1 & 0.536 & 0.334 & 0.358 & 0.425 & 0.850 & 0.488 & 0.581 & 0.492 \\
\hline & SAP2 & 0.513 & 0.394 & 0.404 & 0.445 & 0.894 & 0.523 & 0.573 & 0.517 \\
\hline & SAP3 & 0.515 & 0.417 & 0.394 & 0.435 & 0.817 & 0.506 & 0.568 & 0.517 \\
\hline \multirow{3}{*}{ Social influence } & SI1 & 0.499 & 0.370 & 0.322 & 0.461 & 0.455 & 0.832 & 0.568 & 0.631 \\
\hline & SI2 & 0.483 & 0.343 & 0.324 & 0.347 & 0.490 & 0.818 & 0.491 & 0.536 \\
\hline & SI3 & 0.515 & 0.378 & 0.317 & 0.394 & 0.529 & 0.839 & 0.475 & 0.586 \\
\hline \multirow{4}{*}{ Student satisfaction } & SS1 & 0.565 & 0.403 & 0.344 & 0.537 & 0.574 & 0.545 & 0.848 & 0.623 \\
\hline & SS2 & 0.511 & 0.448 & 0.416 & 0.512 & 0.568 & 0.503 & 0.844 & 0.512 \\
\hline & SS3 & 0.480 & 0.376 & 0.448 & 0.475 & 0.583 & 0.514 & 0.863 & 0.515 \\
\hline & SS4 & 0.533 & 0.388 & 0.423 & 0.517 & 0.573 & 0.547 & 0.865 & 0.553 \\
\hline \multirow{3}{*}{ Task-technology fit } & TTF1 & 0.591 & 0.422 & 0.301 & 0.455 & 0.535 & 0.649 & 0.591 & 0.905 \\
\hline & TTF2 & 0.632 & 0.427 & 0.260 & 0.478 & 0.551 & 0.638 & 0.570 & 0.927 \\
\hline & TTF3 & 0.583 & 0.444 & 0.289 & 0.496 & 0.536 & 0.636 & 0.599 & 0.890 \\
\hline
\end{tabular}

Table 3. Factors loadings and confirmatory factor analysis results.

\begin{tabular}{|c|c|c|c|c|c|c|}
\hline Factors & Items & $\begin{array}{l}\text { Factors } \\
\text { Loadings }\end{array}$ & AVE & $\begin{array}{l}\text { Composite } \\
\text { Reliability }\end{array}$ & R Square & $\begin{array}{c}\text { Cronbach's } \\
\text { Alpha }\end{array}$ \\
\hline \multirow{3}{*}{ e-learning use as sustainability } & EUS1 & 0.869 & 0.744 & 0.897 & 0.537 & 0.828 \\
\hline & EUS2 & 0.867 & & & & \\
\hline & EUS3 & 0.850 & & & & \\
\hline \multirow{3}{*}{ Perceived enjoyment } & PE1 & 0.903 & 0.847 & 0.943 & & 0.909 \\
\hline & PE2 & 0.932 & & & & \\
\hline & PE3 & 0.925 & & & & \\
\hline \multirow{3}{*}{ Perceived ease of use } & PEU1 & 0.810 & 0.707 & 0.879 & & 0.793 \\
\hline & PEU2 & 0.869 & & & & \\
\hline & PEU3 & 0.843 & & & & \\
\hline \multirow{3}{*}{ Perceived usefulness } & PU1 & 0.902 & 0.723 & 0.886 & & 0.804 \\
\hline & PU2 & 0.891 & & & & \\
\hline & PU3 & 0.748 & & & & \\
\hline
\end{tabular}


Table 3. Cont.

\begin{tabular}{|c|c|c|c|c|c|c|}
\hline Factors & Items & $\begin{array}{c}\text { Factors } \\
\text { Loadings }\end{array}$ & AVE & $\begin{array}{l}\text { Composite } \\
\text { Reliability }\end{array}$ & R Square & $\begin{array}{c}\text { Cronbach's } \\
\text { Alpha }\end{array}$ \\
\hline \multirow{3}{*}{ Student academic performance } & SAP1 & 0.850 & 0.730 & 0.890 & 0.527 & 0.814 \\
\hline & SAP2 & 0.894 & & & & \\
\hline & SAP3 & 0.817 & & & & \\
\hline \multirow{3}{*}{ Social influence } & SI1 & 0.832 & 0.688 & 0.869 & & 0.774 \\
\hline & SI2 & 0.818 & & & & \\
\hline & SI3 & 0.839 & & & & \\
\hline \multirow{4}{*}{ Student satisfaction } & SS1 & 0.848 & 0.731 & 0.916 & 0.478 & 0.877 \\
\hline & SS2 & 0.844 & & & & \\
\hline & SS3 & 0.863 & & & & \\
\hline & SS4 & 0.865 & & & & \\
\hline \multirow{3}{*}{ Task-technology fit } & TTF1 & 0.905 & 0.824 & 0.933 & 0.550 & 0.893 \\
\hline & TTF2 & 0.927 & & & & \\
\hline & TTF3 & 0.890 & & & & \\
\hline
\end{tabular}

Table 4. Discriminant validity.

\begin{tabular}{|c|c|c|c|c|c|c|c|c|}
\hline Factors & EUS & PEU & PE & PU & SI & SAP & SS & TTF \\
\hline e-learning use as sustainability & 0.905 & & & & & & & \\
\hline Perceived ease of use & 0.378 & 0.927 & & & & & & \\
\hline Perceived enjoyment & 0.540 & 0.355 & 0.907 & & & & & \\
\hline Perceived usefulness & 0.508 & 0.377 & 0.620 & 0.923 & & & & \\
\hline Social influence & 0.602 & 0.387 & 0.439 & 0.485 & 0.911 & & & \\
\hline Student academic performance & 0.610 & 0.451 & 0.446 & 0.509 & 0.592 & 0.900 & & \\
\hline Student satisfaction & 0.612 & 0.476 & 0.472 & 0.598 & 0.618 & 0.672 & 0.903 & \\
\hline Task-technology fit & 0.663 & 0.312 & 0.475 & 0.525 & 0.706 & 0.596 & 0.646 & 0.899 \\
\hline
\end{tabular}

\subsection{The Analysis of the Structural Model}

To validate the research hypotheses and examine construct relationships, Smart PLS 2.0 was used. The hypothesis is seen in Figure 1, the path coefficient findings in Figure 2, and the path (T-Values) findings in Figure 3.

Table 5 summarizes the results of the study, including all partnerships. For the relationship between perceived usefulness -> e-learning use as sustainability (H1) $(\beta=0.502$, $\mathrm{SE}=0.100, \mathrm{t}=1.659, p<0.001)$, the hypothesis was accepted. For the relationship between perceived usefulness $\rightarrow$ task-technology fit $(\mathrm{H} 2)(\beta=0.180, \mathrm{SE}=0.098, \mathrm{t}=1.900$, $p<0.001)$, the hypothesis was accepted. For the relationship between perceived ease of use $->$ e-learning use as sustainability $(\mathrm{H} 3)(\beta=0.577, \mathrm{SE}=0.095, \mathrm{t}=1.808, p<0.001)$, the hypothesis was accepted. Similarly, for the relationship between perceived ease of use $->$ task-technology fit $(\mathrm{H} 4)(\beta=0.531, \mathrm{SE}=0.088, \mathrm{t}=1.773, p<0.001)$, the hypothesis was accepted. For the relationship between perceived enjoyment $->$ e-learning use as sustainability (H5) $(\beta=0.215, \mathrm{SE}=0.119, \mathrm{t}=1.809, p<0.001)$, the hypothesis was accepted. For the relationship between perceived enjoyment $->$ task-technology fit (H6) $(\beta=0.118, \mathrm{SE}=0.095, \mathrm{t}=1.741, p<0.001)$, the hypothesis was accepted. In addition, for the relationship between social influence -> e-learning use as sustainability (H7) $(\beta=0.178$, $\mathrm{SE}=0.126, \mathrm{t}=1.808, p<0.001)$, the hypothesis was accepted. For the relationship between social influence $->$ task-technology fit $(\mathrm{H} 8)(\beta=0.574, \mathrm{SE}=0.084, \mathrm{t}=6.812, p<0.001)$, the 
hypothesis was accepted. For the relationship between task-technology fit -> e-learning use as sustainability (H9) $(\beta=0.377, \mathrm{SE}=0.126, \mathrm{t}=2.995, p<0.001)$, the hypothesis was accepted. Moreover, for the relationship between task-technology fit $\rightarrow>$ student satisfaction $(\mathrm{H} 10)(\beta=0.429, \mathrm{SE}=0.111, \mathrm{t}=3.862, p<0.001)$, the hypothesis was accepted. For the relationship between task-technology fit $->$ student academic performance $(\mathrm{H} 11)(\beta=0.163$, $\mathrm{SE}=0.126, \mathrm{t}=1.594, p<0.001)$, the hypothesis was accepted. For the relationship between e-learning use as sustainability -> student satisfaction $(\mathrm{H} 12)(\beta=0.328, \mathrm{SE}=0.102, \mathrm{t}=3.224$, $p<0.001)$, the hypothesis was accepted. For the relationship between e-learning use as sustainability $\rightarrow$ student academic performance $(\mathrm{H} 13)(\beta=0.248, \mathrm{SE}=0.092, \mathrm{t}=2.688$, $p<0.001)$, the hypothesis was accepted. Finally, for the relationship between student satisfaction $->$ student academic performance $(\mathrm{H} 14)(\beta=0.415, \mathrm{SE}=0.105, \mathrm{t}=3.953, p<0.001)$, the hypothesis was accepted.

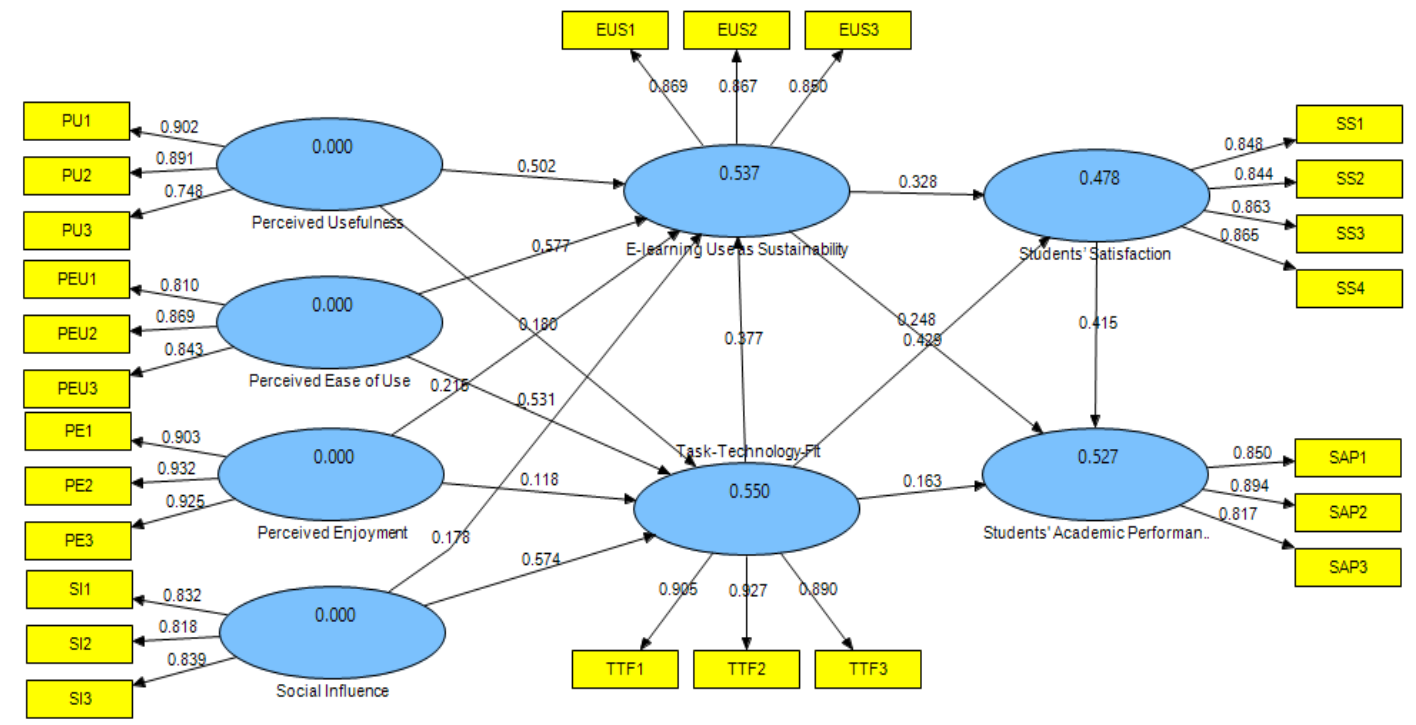

Figure 2. Path coefficient findings.

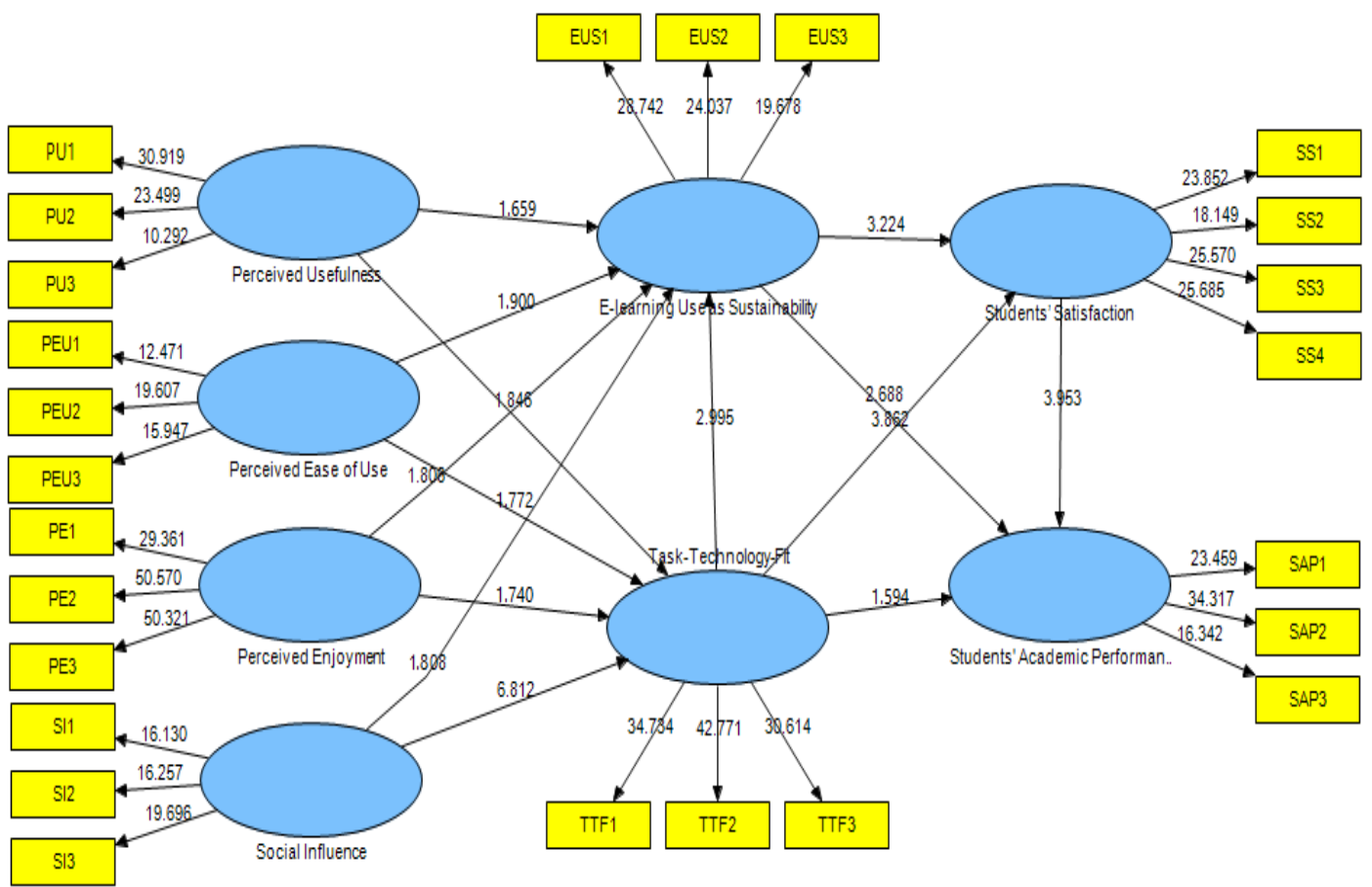

Figure 3. Path (T-Values) findings. 
Table 5. Hypotheses testing.

\begin{tabular}{|c|c|c|c|c|}
\hline Path of Hypotheses & Path Coefficient & Standard Error & T-Values & Results \\
\hline Perceived usefulness -> e-learning use as sustainability $(\mathrm{H} 1)$ & 0.502 & 0.100 & 1.659 & Accepted \\
\hline Perceived usefulness $->$ Task-technology fit $(\mathrm{H} 2)$ & 0.180 & 0.098 & 1.900 & Accepted \\
\hline Perceived ease of use -> e-learning use as sustainability (H3) & 0.577 & 0.095 & 1.808 & Accepted \\
\hline Perceived ease of use -> Task-technology fit (H4) & 0.531 & 0.088 & 1.773 & Accepted \\
\hline Perceived enjoyment -> e-learning use as sustainability (H5) & 0.215 & 0.119 & 1.809 & Accepted \\
\hline Perceived enjoyment -> Task-technology fit (H6) & 0.118 & 0.095 & 1.741 & Accepted \\
\hline Social influence -> e-learning use as sustainability (H7) & 0.178 & 0.126 & 1.808 & Accepted \\
\hline Social influence -> Task-technology fit (H8) & 0.574 & 0.084 & 6.812 & Accepted \\
\hline Task-technology fit -> e-learning use as sustainability (H9) & 0.377 & 0.126 & 2.995 & Accepted \\
\hline Task-technology fit -> Student satisfaction (H10) & 0.429 & 0.111 & 3.862 & Accepted \\
\hline Task-technology fit -> Student academic performance (H11) & 0.163 & 0.126 & 1.594 & Accepted \\
\hline e-learning use as sustainability $->$ Student satisfaction (H12) & 0.328 & 0.102 & 3.224 & Accepted \\
\hline e-learning use as sustainability -> Student academic performance (H13) & 0.248 & 0.092 & 2.688 & Accepted \\
\hline Student satisfaction $->$ Student academic performance (H14) & 0.415 & 0.105 & 3.953 & Accepted \\
\hline
\end{tabular}

\section{Discussion and Implications}

Theoretically, this study improved understanding of how to use e-learning as a source of educational sustainability by developing a research model focused on the role of tasktechnology fit (TTF) as a source of sustainability in higher education. In the study model, determinant TTF and TAM variables include perceived usefulness, perceived ease of use, perceived enjoyment, social influence, e-learning use as sustainability, task-technology fit, student satisfaction, and student academic performance. As a result, the research model identifies TTF and TAM variables as having the largest impact on student satisfaction and academic performance by using e-learning as a sustainability for education strategy. Therefore, the study's findings strongly support the perceived usefulness variable, which confirms hypotheses one and two, indicating that perceived usefulness has a positive impact on e-learning usage as sustainability in education and task-technology fit. To put it another way, when an e-learning system is beneficial and acceptable (Fit), the higher perceived usefulness contributes to increased use of the e-learning system as sustainability in education, and hence technology is fit. The significance of perceived usefulness in the field of e-learning has been examined by a number of scholars. Therefore, the results of this study confirm previous relationships between factors [72-75]. In addition, the study's findings strongly support the perceived ease of use variable, which confirms hypotheses three and four, indicating that perceived ease of use has a positive impact on e-learning usage as sustainability in education and task-technology fit. To put it another way, when an e-learning system is easy to use and acceptable (Fit), the higher perceived ease of use contributes to increased use of the e-learning system as sustainability in education, and hence technology is fit. The significance of perceived ease of use in the field of e-learning has been examined by a number of researchers. Thus, the results of this study confirm previous relationships between factors [55,76-78]. Similarly, the study's findings strongly support the perceived enjoyment variable, which confirms hypotheses five and six, indicating that perceived enjoyment has a positive impact on e-learning usage as sustainability in education and task-technology fit. To put it another way, when an e-learning system is enjoyable and acceptable (Fit), the higher perceived enjoyment contributes to increased use of the e-learning system as sustainability in education, and hence technology is fit. The significance of perceived enjoyment in the field of e-learning has been examined by a number of researchers. Thus, the results of this research confirm previous findings [79-82]. Additionally, the findings in this research strongly support the social influence variable, which confirms hypotheses seven and eight, indicating that social influence has a positive impact on e-learning usage as sustainability in education and task-technology fit. To put it another way, when an e-learning system affects social influence and is acceptable 
(Fit), the higher social influence contributes to increased use of the e-learning system as sustainability in education, and hence technology is fit. The significance of social influence in the field of e-learning has been examined by previous researchers. Therefore, the results of this research confirm previous relationships between factors [83-86]. Further, this research shows the findings strongly support the task-technology fit variable, which confirms hypotheses nine, ten, and eleven, indicating that task-technology fit has a positive impact on e-learning usage as sustainability in education, student satisfaction, and student academic performance. To put it another way, when an e-learning system is affected by task-technology fit and is acceptable, the higher task-technology fit contributes to increased use of the e-learning system as sustainability in education, student satisfaction, and student academic performance. The significance of social influence in the field of e-learning has been examined by previous researchers. Therefore, the results of this research confirm previous relationships between factors [87,88]. Moreover, the findings in this research strongly support the e-learning system use as sustainability variable, which confirms hypotheses twelve and thirteen, indicating that e-learning system use as sustainability has a positive impact on student satisfaction and student academic performance. To put it another way, when an e-learning system is affected by e-learning system use as sustainability and is acceptable, the higher e-learning system use contributes to increased use of the e-learning system as sustainability in education, student satisfaction, and student academic performance. The significance of social influence in the field of e-learning has been examined by previous researchers. The results of this research therefore confirm previous relationships between factors $[9,89,90]$. Finally, the study's findings strongly support the student satisfaction variable, which confirms hypothesis fourteen, indicating that student satisfaction has a positive impact on e-learning usage as sustainability in education and student academic performance. To put it another way, when an e-learning system is beneficial and acceptable (enjoyable, easy to use, and useful), the higher student satisfaction contributes to increased use of the e-learning system as sustainability in education, and hence affects student academic performance. The significance of student satisfaction in the field of e-learning has been examined by a number of scholars. Therefore, the results of this study confirm previous relationships between factors [33,91-94]. Based on the model and the results, this analysis has a number of implications. The first implication has to do with the value of agreed constructs. The positive relationship between perceived usefulness, perceived ease of use, perceived enjoyment, and social influence is particularly important in the role of technology fit of e-learning use as a source of learning sustainability. Second, faculty can demonstrate how to use technology by providing students with teaching resources that can help them learn how to use it, keeping in mind that e-learning should be seen as both easy to use and useful. Third, students should be educated on the many advantages of using technology, as well as provided with course material or other learning objectives related to long-term learning sustainability, which in turn increases student satisfaction and student academic performance. While this research shows that statistical support is available, there are several limitations to this research. Since the respondents in this sample are all from the same institution, subsequent research would need more respondents from a variety of majors. Since there was no qualitative evidence in the sample, it was based on students' expectations, which could differ from teachers' perceptions. It is advised that subsequent experiments be duplicated in other nations.

\section{Conclusion and Future Works}

According to the results, perceived usefulness, perceived ease of use, perceived enjoyment, and social influence are all significant factors affecting the role of technology fit in e-learning use as a way of learning sustainability. Moreover, students' satisfaction has been shown to have an effect on their academic performance. The study's findings may encourage developers of e-learning systems that are used for sustainability learning to understand these factors that influence user satisfaction and academic performance. Furthermore, this research can lead in the right direction for cultivating student satisfaction 
in order to enable them to use e-learning as a sustainability learning strategy. TTF and the TAM were validated in the current research in an educational context, giving further insight into students' future perceptions of the use of e-learning systems as a source of learning sustainability. The hypotheses of the proposed paradigm of e-learning usage for sustainability in higher education were adopted in this study. The study found that combining TTF and the TAM will positively influence the study's outcome, and that the role of task-technology fit (TTF) has a positive impact on e-learning acceptance for long-term sustainability in higher education. More research into the relationships between the complexity of e-learning systems and the links between e-learning systems and other education systems such as massive open online courses (MOOCs) and learning management systems (LMS) is necessary in higher education. Follow-up research is also needed to investigate the roles of observability and trialability in e-learning, especially in terms of adaptation and sustainability in higher education.

Funding: This research received no external funding.

Institutional Review Board Statement: Not applicable.

Informed Consent Statement: Not applicable.

Data Availability Statement: Not applicable.

Acknowledgments: The Author acknowledges the Deanship of Scientific Research at King Faisal University for the financial support under Nasher Track 2021 (Grant No. 216093).

Conflicts of Interest: The authors declare no conflict of interest.

\section{Appendix A}

\begin{tabular}{|c|c|}
\hline Code & Items \\
\hline PU1 & Using the e-learning system improves my course performance. \\
\hline PU2 & Using the e-learning system improves my productivity in courses. \\
\hline PU3 & I find the e-learning system useful for my studies. \\
\hline PEU1 & I find the e-learning system easy to use. \\
\hline PEU2 & My interaction with the e-learning system is clear and understandable. \\
\hline PEU3 & It would be easy for me to find the required information for using e-learning. \\
\hline PE1 & I find the e-learning system process enjoyable. \\
\hline PE2 & The actual process of using the e-learning system is pleasant. \\
\hline PE3 & I have fun using the e-learning system. \\
\hline SI1 & My instructors think that I should participate in e-learning system activities. \\
\hline SI2 & My peers think that I should participate in e-learning system activities. \\
\hline SI3 & The management of my university thinks that I should use e-learning system activities. \\
\hline EUS1 & I use the e-learning system frequently. \\
\hline EUS2 & I tend to use the e-learning system frequently. \\
\hline EUS3 & I spend a lot of time exploring within the e-learning system. \\
\hline TTF1 & I think that using e-learning is well suited for the way to learn. \\
\hline TTF2 & E-learning is a good tool to provide the way I like to study tasks. \\
\hline TTF3 & Using e-learning fits well for the way I like to study tasks. \\
\hline SS1 & The e-learning system is effective for gathering knowledge. \\
\hline SS2 & The e-learning system is efficient for the construction of knowledge. \\
\hline SS3 & The e-learning system is efficient for the exchange of knowledge. \\
\hline SS4 & I am satisfied with using the e-learning system as a learning tool. \\
\hline SAP1 & I feel the e-learning system helps me improve my creativity. \\
\hline SAP2 & I feel the e-learning system helps me improve my knowledge and information. \\
\hline SAP3 & I feel the e-learning system helps me improve my experiences and performance. \\
\hline
\end{tabular}




\section{References}

1. Al-Rahmi, W.M.; Yahaya, N.; Aldraiweesh, A.A.; Alamri, M.M.; Aljarboa, N.A.; Alturki, U.; Aljeraiwi, A.A. Integrating technology acceptance model with innovation diffusion theory: An empirical investigation on students' intention to use E-learning systems. IEEE Access 2019, 7, 26797-26809. [CrossRef]

2. Al-Fraihat, D.; Joy, M.; Masa'Deh, R.; Sinclair, J. Evaluating E-learning systems success: An empirical study. Comput. Hum. Behav. 2020, 102, 67-86. [CrossRef]

3. Cidral, W.A.; Oliveira, T.; Di Felice, M.; Aparicio, M. E-learning success determinants: Brazilian empirical study. Comput. Educ. 2018, 122, 273-290. [CrossRef]

4. Klobas, J.E.; McGill, T.J. The role of involvement in learning management system success. J. Comput. High. Educ. 2010, 22, 114-134. [CrossRef]

5. Eom, S.; Ashill, N.J.; Arbaugh, J.; Stapleton, J.L. The role of information technology in e-learning systems success. Hum. Syst. Manag. 2012, 31, 147-163. [CrossRef]

6. Hassanzadeh, A.; Kanaani, F.; Elahi, S. A model for measuring e-learning systems success in universities. Expert Syst. Appl. 2012, 39, 10959-10966. [CrossRef]

7. Sawangchai, A.; Prasarnkarn, H.; Kasuma, J.; Polyakova, A.G.; Qasim, S. Effects of COVID-19 on digital learning of entrepreneurs. Pol. J. Manag. Stud. 2020, 22, 502-517.

8. Al-Rahmi, W.M.; Othman, M.S.; Yusuf, L.M. Exploring the factors that affect student satisfaction through using e-learning in Malaysian higher education institutions. Mediter. J. Soc. Sci. 2015, 6, 299. [CrossRef]

9. Alam, M.M.; Ahmad, N.; Naveed, Q.N.; Patel, A.; Abohashrh, M.; Khaleel, M.A. E-Learning Services to Achieve Sustainable Learning and Academic Performance: An Empirical Study. Sustainability 2021, 13, 2653. [CrossRef]

10. Al-Rahmi, W.M.; Alzahrani, A.I.; Yahaya, N.; Alalwan, N.; Kamin, Y.B. Digital communication: Information and communication technology (ICT) usage for education sustainability. Sustainability 2020, 12, 5052. [CrossRef]

11. Ahmad, N. Cloud computing: Technology, security issues and solutions. In Proceedings of the 2nd International Conference on Anti-Cyber Crimes (ICACC), Abha, Saudi Arabia, 26-27 March 2017; pp. 30-35.

12. Al-Rahmi, W.M.; Aldraiweesh, A.; Yahaya, N.; Kamin, Y.B. Massive open online courses (MOOCS): Systematic literature review in Malaysian higher education. Int. J. Eng. Technol. 2018, 7, 2197-2202. [CrossRef]

13. Irfan, M.; Ahmad, N. Internet of medical things: Architectural model, motivational factors and impediments. In Proceedings of the 15th Learning and Technology Conference (L\&T), Jeddah, Saudi Arabia, 25-26 February 2018; pp. 6-13.

14. Khan, N.; Naim, A.; Hussain, M.R.; Naveed, Q.N.; Ahmad, N.; Qamar, S. The 51 V's of Big Data: Survey, Technologies, Characteristics, Opportunities, Issues and Challenges. In Proceedings of the International Conference on Omni-Layer Intelligent Systems, Crete, Greece, 5-7 May 2019; pp. 19-24.

15. Al-Rahmi, W.M.; Yahaya, N.; Aldraiweesh, A.A.; Alturki, U.; Alamri, M.M.; Saud, M.S.B.; Kamin, Y.; Aljeraiwi, A.A.; Alhamed, O.A. Big data adoption and knowledge management sharing: An empirical investigation on their adoption and sustainability as a purpose of education. IEEE Access 2019, 7, 47245-47258. [CrossRef]

16. Alamri, M.M.; Almaiah, M.A.; Al-Rahmi, W.M. Social media applications affecting Students' academic performance: A model developed for sustainability in higher education. Sustainability 2020, 12, 6471. [CrossRef]

17. Alamri, M.M.; Almaiah, M.A.; Al-Rahmi, W.M. The Role of Compatibility and Task-Technology Fit (TTF): On Social Networking Applications (SNAs) Usage as Sustainability in Higher Education. IEEE Access 2020, 8, 161668-161681. [CrossRef]

18. Ullah, N.; Alnumay, W.S.; Al-Rahmi, W.M.; Alzahrani, A.I.; Al-Samarraie, H. Modeling cost saving and innovativeness for blockchain technology adoption by energy management. Energies 2020, 13, 4783. [CrossRef]

19. Ullah, N.; Mugahed Al-Rahmi, W.; Alzahrani, A.I.; Alfarraj, O.; Alblehai, F.M. Blockchain Technology Adoption in Smart Learning Environments. Sustainability 2021, 13, 1801. [CrossRef]

20. Ahmad, N.; Mehmood, R. Enterprise Systems for Networked Smart Cities. In Deep Learning and Edge Computing Solutions for High Performance Computing; Springer International Publishing: Berlin/Heidelberg, Germany, 2019; pp. 1-33.

21. Almaiah, M.A.; Alamri, M.M.; Al-Rahmi, W.M. Applying the UTAUT model to explain the students' acceptance of mobile learning system in higher education. IEEE Access 2019, 7, 174673-174686. [CrossRef]

22. Naveed, Q.N.; Qureshi, M.R.N.M.; Shaikh, A.; Alsayed, A.; Sanober, S.; Mohiuddin, K. Evaluating and Ranking Cloud-Based E-Learning Critical Success Factors (CSFs) Using Combinatorial Approach. IEEE Access 2019, 7, 157145-157157. [CrossRef]

23. Almaiah, M.A.; Alamri, M.M.; Al-Rahmi, W.M. Analysis the effect of different factors on the development of Mobile learning applications at different stages of usage. IEEE Access 2019, 8, 16139-16154.

24. Smolag, K.; Slusarczyk, B.; Kot, S. The Role of Social Media in Management of Relational Capital in Universities. Prabandhan Indian J. Manag. 2016, 9, 34. [CrossRef]

25. Gunn, C. Sustainability factors for e-learning initiatives. ALT J. 2010, 18, 89-103. [CrossRef]

26. Azeiteiro, U.; Leal Filho, W.; Caeiro, S. E-Learning and Education for Sustainability; Universidade Aberta (UAb): Lisbon, Portugal, 2014; pp. 1-290.

27. Castle, S.R.; McGuire, C.J. An analysis of student self-assessment of online, blended, and face-to-face learning environments: Implications for sustainable education delivery. Int. Educ. Stud. 2010, 3, 36-40. [CrossRef]

28. Isaias, P.; Issa, T. E-learning and sustainability in higher education: An international case study. Int. J. Learn. High. Educ. 2013, 20, 77-90. [CrossRef] 
29. Johnson, R.D.; Brown, K.G. E-learning. In The Wiley Blackwell Handbook of the Psychology of the Internet at Work; Wiley: Hoboken, NJ, USA, 2017; pp. 369-400.

30. Davis, F.D.; Venkatesh, V. A critical assessment of potential measurement biases in the technology acceptance model: Three experiments. Int. J. Hum. Comput. Stud. 1996, 45, 19-45. [CrossRef]

31. Delone, W.H.; McLean, E.R. The DeLone and McLean Model of Information Systems Success: A Ten-Year Update. J. Manag. Inf. Syst. 2003, 19, 9-30.

32. Sadaf, A.; Newby, T.J.; Ertmer, P.A. Exploring Factors that Predict Preservice Teachers' Intentions to Use Web 2.0 Technologies Using Decomposed Theory of Planned Behavior. J. Res. Technol. Educ. 2012, 45, 171-196. [CrossRef]

33. Alsabawy, A.Y.; Cater-Steel, A.; Soar, J. IT infrastructure services as a requirement for e-learning system success. Comput. Educ. 2013, 69, 431-451. [CrossRef]

34. Vasconcelos, P.; Furtado, E.S.; Pinheiro, P.; Furtado, L. Multidisciplinary criteria for the quality of e-learning services design. Comput. Hum. Behav. 2020, 107, 105979. [CrossRef]

35. Yilmaz, R. Exploring the role of e-learning readiness on student satisfaction and motivation in flipped classroom. Comput. Hum. Behav. 2017, 70, 251-260. [CrossRef]

36. Kanwal, F.; Rehman, M. Measuring Information, System and Service Qualities for the Evaluation of E-Learning Systems in Pakistan. Pak. J. Sci. 2016, 68, 302-307.

37. Stuss, M.M.; Szczepa 'nska-Woszczyna, K.; Makieła, Z.J. Competences of Graduates of Higher Education Business Studies in Labor Market I (Results of Pilot Cross-Border Research Project in Poland and Slovakia). Sustainability 2019, 11, 4988. [CrossRef]

38. Alhussain, T.; Al-Rahmi, W.M.; Othman, M.S. Students' Perceptions of Social Networks Platforms use in Higher Education: A Qualitative Research. Int. J. Adv. Trends Comput. Sci. Eng. 2020, 9, 2589-2603. [CrossRef]

39. Davis, F.D. Perceived usefulness, perceived ease of use, and user acceptance of information technology. MIS Q. 1989, 13, 319-340. [CrossRef]

40. Goodhue, D.L.; Thompson, R.L. Task-technology and individual performance. MIS Q. 1995, 19, 213-236. [CrossRef]

41. Khazanchi, D. Information Technology (IT) Appropriateness: The Contingency Theory of " and IT Implementation in Small and Medium Enterprises. J. Comput. Inf. Syst. 2005, 45, 88-95.

42. McGill, T.J.; Klobas, J.E. A task-technology view of learning management system impact. Comput. Educ. 2009, 52, 496-508. [CrossRef]

43. Alenazy, W.M.; Al-Rahmi, W.M.; Khan, M.S. Validation of TAM model on social media use for collaborative learning to enhance collaborative authoring. IEEE Access 2019, 7, 71550-71562. [CrossRef]

44. Al-Maatouk, Q.; Othman, M.S.; Aldraiweesh, A.; Alturki, U.; Al-Rahmi, W.M.; Aljeraiwi, A.A. Task-technology fit and technology acceptance model application to structure and evaluate the adoption of social media in academia. IEEE Access 2020, 8, 78427-78440. [CrossRef]

45. Rogers, E.M. Diffusion of preventive innovations. Addict. Behav. 2002, 27, 989-993. [CrossRef]

46. Preece, J. Sociability and usability in online communities: Determining and measuring success. Behav. Inf. Technol. 2001, 20, 347-356. [CrossRef]

47. Venkatesh, V.; Davis, F.D. A theoretical extension of the technology acceptance model: Four longitudinal field studies. Manag. Sci. 2000, 46, 186-204. [CrossRef]

48. Van der Heijden, H. User acceptance of hedonic information systems. MIS Q. 2004, 28, 695-704. [CrossRef]

49. Venkatesh, V.; Morris, M.G.; Davis, G.B.; Davis, F.D. User acceptance of information technology: Toward a unified view. MIS Q. 2003, 27, 425-478. [CrossRef]

50. Im, I.; Hong, S.; Kang, M.S. An international comparison of technology adoption: Testing the UTAUT model. Inf. Manag. 2011, 48, 1-8. [CrossRef]

51. Yulius, R.; Santosa, P.I.; Hartanto, R. E-Learning Acceptance Factors of Universitas Sahid Surakarta. In Proceedings of the First International Conference on Technology, Innovation, and Society (ICTIS), West Sumatra, Indonesia, 21-22 July 2016.

52. Rossi, P.G. Learning environment with artificial intelligence elements. J. E-Learn. Knowl. Soc. 2009, 5, 67-75.

53. Algahtani, A.F. Evaluating the Effectiveness of the E-learning Experience in Some Universities in Saudi Arabia from Male Students' Perceptions. Ph.D. Theses, Durham University, Durham, UK, 2011.

54. Zeitoun, H. E-Learning: Concept, Issues, Application, Evaluation, Riyadh; Dar Alsolateah Publication: Riyadh, Saudi Arabia, 2008.

55. Abbad, M.; Morris, D.; Al-Ayyoub, A.E. Studentsâ?? Decisions to Use an eLearning System: A Structural Equation Modelling Analysis. Int. J. Emerg. Technol. Learn. 2009, 4, 4-13. [CrossRef]

56. Zhang, T.; Shaikh, Z.A.; Yumashev, A.V.; Chład, M. Applied Model of E-Learning in the Framework of Education for Sustainable Development. Sustainability 2020, 12, 6420. [CrossRef]

57. Goodhue, D.L. Understanding user evaluations of information systems. Manag. Sci. 1995, 41, 1827-1844. [CrossRef]

58. Wang, Y. Assessment of learner satisfaction with asynchronous electronic learning systems. Inf. Manag. 2003, 41, 75-86. [CrossRef]

59. Lu, H.P.; Chiou, M.J. The impact of individual differences on e-learning system satisfaction: A contingency approach. Br. J. Educ. Technol. 2010, 41, 307-323. [CrossRef]

60. Islam, A.N. Investigating e-learning system usage outcomes in the university context. Comput. Educ. 2013, 69, 387-399. [CrossRef]

61. McDowall, T.; Jackling, B. The Impact of Computer-Assisted Learning on Academic Grades: An Assessment of Students'Perceptions. Account. Educ. 2006, 15, 377-389. [CrossRef] 
62. Alyoussef, I.Y.; Alamri, M.M.; Al-Rahmi, W.M. Social media use (SMU) for teaching and learning in Saudi Arabia. Int. J. Recent Technol. Eng. 2019, 8, 942-946.

63. Alalwan, N.; Al-Rahmi, W.M.; Alfarraj, O.; Alzahrani, A.; Yahaya, N.; Al-Rahmi, A.M. Integrated three theories to develop a model of factors affecting students' academic performance in higher education. IEEE Access 2019, 7, 98725-98742. [CrossRef]

64. Hair, J.F.; Risher, J.; Sarstedt, M.; Ringle, C. When to use and how to report the results of PLS-SEM. Eur. Bus. Rev. 2019, 31, 2-24. [CrossRef]

65. Sekaran, U.; Bougie, R. Research Methods for Business: A Skill Building Approach; Wiley: Hoboken, NJ, USA, 2016.

66. Sun, P.C.; Tsai, R.J.; Finger, G.; Chen, Y.Y.; Yeh, D. What drives a successful elearning? An empirical investigation of the critical factors influencing learner satisfaction. Comput. Educ. 2008, 50, 1183-1202. [CrossRef]

67. Kim, T.; Suh, Y.K.; Lee, G.; Choi, B.G. Modelling roles of task-technology fit and self-efficacy in hotel employees' usage behaviours of hotel information systems. Int. J. Tour. Res. 2010, 12, 709e725. [CrossRef]

68. Wu, B.; Zhang, C.Y. Empirical study on continuance intentions towards ELearning 2.0 systems. Behav. Inf. Technol. 2014, 33, 1027-1038. [CrossRef]

69. Culibrk, L.; Croft, C.A.; Tebbutt, S.J. Systems biology approaches for host-fungal interactions: An expanding multi-omics frontier. OMICS 2016, 20, 127-138. [CrossRef] [PubMed]

70. Ing, H.C.; Yahaya, N.; Kumar, L.; Al-Rahmi, W.M. Examining Learners' Interaction Pattern in Asynchronous Text-Based Online Learning. i-Manager's J. Educ. Technol. 2020, 16, 9.

71. Chow, Y.S.; Teicher, H. Probability Theory: Independence, Interchangeability, Martingales; Springer Science Business Media: Berlin, Germany, 2012.

72. Mailizar, M.; Burg, D.; Maulina, S. Examining university students' behavioural intention to use e-learning during the COVID-19 pandemic: An extended TAM model. Educ. Inf. Technol. 2021, 26, 1-21.

73. Al-Rahmi, W.; Aldraiweesh, A.; Yahaya, N.; Kamin, Y.B.; Zeki, A.M. Massive open online courses (MOOCs): Data on higher education. Data Brief 2019, 22, 118-125. [CrossRef] [PubMed]

74. Al-Gahtani, S.S. Empirical investigation of e-learning acceptance and assimilation: A structural equation model. Appl. Comput. Inform. 2016, 12, 27-50. [CrossRef]

75. Kimathi, F.A.; Zhang, Y. Exploring the general extended technology acceptance model for e-learning approach on student's usage intention on e-learning system in University of Dar es Salaam. Create. Educ. 2019, 10, 208-223. [CrossRef]

76. Naveed, Q.N.; Alam, M.M.; Tairan, N. Structural Equation Modeling for Mobile Learning Acceptance by University Students: An Empirical Study. Sustainability 2020, 12, 8618. [CrossRef]

77. Moafa, F.A.; Ahmad, K.; Al-Rahmi, W.M.; Yahaya, N.; Kamin, Y.B.; Alamri, M.M. Develop a model to measure the ethical effects of students through social media use. IEEE Access 2018, 6, 56685-56699. [CrossRef]

78. Esteban-Millat, I.; Martínez-López, F.J.; Pujol-Jover, M.; Gázquez-Abad, J.C.; Alegret, A. An extension of the technology acceptance model for online learning environments. Interact. Learn. Environ. 2018, 26, 895-910. [CrossRef]

79. Castiblanco Jimenez, I.A.; Cepeda García, L.C.; Violante, M.G.; Marcolin, F.; Vezzetti, E. Commonly Used External TAM Variables in e-Learning, Agriculture and Virtual Reality Applications. Future Internet 2021, 13, 7. [CrossRef]

80. Abuhassna, H.; Al-Rahmi, W.M.; Yahya, N.; Zakaria, M.A.Z.M.; Kosnin, A.B.M.; Darwish, M. Development of a new model on utilizing online learning platforms to improve students' academic achievements and satisfaction. Int. J. Educ. Technol. High. Educ. 2020, 17, 1-23. [CrossRef]

81. Munabi, S.K.; Aguti, J.; Nabushawo, H.M. Using the TAM Model to Predict Undergraduate Distance Learners Behavioural Intention to Use the Makerere University Learning Management System. Open Access Libr. J. 2020, 7, 1-12. [CrossRef]

82. Balog, A.; Pribeanu, C. The role of perceived enjoyment in the students' acceptance of an augmented reality teaching platform: A structural equation modelling approach. Stud. Inform. Control 2010, 19, 319-330. [CrossRef]

83. Li, C.; He, L.; Wong, I.A. Determinants predicting undergraduates' intention to adopt e-learning for studying english in chinese higher education context: A structural equation modelling approach. Educ. Inf. Technol. 2021, 1-19. [CrossRef]

84. Amsal, A.A.; Putri, S.L.; Rahadi, F.; Fitri, M.E.Y. Perceived Satisfaction and Perceived Usefulness of E-Learning: The Role of Interactive Learning and Social Influence. In Proceedings of the 3rd International Conference on Educational Development and Quality Assurance (ICED-QA 2020), Padang, Indonesia, 3 February 2021; pp. 535-541.

85. Vululleh, P. Determinants of students'e-learning acceptance in developing countries: An approach based on Structural Equation Modeling (SEM). Int. J. Educ. Dev. Using ICT 2018, 14, 141-151.

86. Tarhini, A.; Hone, K.; Liu, X. The effects of individual differences on e-learning users' behaviour in developing countries: A structural equation model. Comput. Hum. Behav. 2014, 41, 153-163. [CrossRef]

87. Lin, W.S.; Wang, C.H. Antecedences to continued intentions of adopting e-learning system in blended learning instruction: A contingency framework based on models of information system success and task-technology fit. Comput. Educ. 2012, 58, 88-99. [CrossRef]

88. Sharma, S.K.; Gaur, A.; Saddikuti, V.; Rastogi, A. Structural equation model (SEM)-neural network (NN) model for predicting quality determinants of e-learning management systems. Behav. Inf. Technol. 2017, 36, 1053-1066. [CrossRef]

89. Ruangvanich, S.; Piriyasurawong, P. Structural Equation Model of Acceptance Cloud Learning for Sustainability Usage in Higher Education Institutes. Int. J. Emerg. Technol. Learn. 2019, 14, 18. [CrossRef] 
90. Al-Rahmi, A.M.; Shamsuddin, A.; Alismaiel, O.A. Task-Technology Fit Model: The Factors Affecting Students' Academic Performance in Higher Education. Univers. J. Educ. Res. 2020, 8, 6831-6843. [CrossRef]

91. Turhangil Erenler, H.H. A structural equation model to evaluate students' learning and satisfaction. Comput. Appl. Eng. Educ. 2020, 28, 254-267. [CrossRef]

92. Cheng, Y.M. Students' satisfaction and continuance intention of the cloud-based e-learning system: Roles of interactivity and course quality factors. Educ. Train. 2020, 62, 1037-1059. [CrossRef]

93. Muhammad, A.; Shaikh, A.; Naveed, Q.N.; Qureshi, M.R.N. Factors Affecting Academic Integrity in E-Learning of Saudi Arabian Universities. An Investigation Using Delphi and AHP. IEEE Access 2020, 8, 16259-16268. [CrossRef]

94. Salloum, S.A.; Shaalan, K. Factors affecting students' acceptance of e-learning system in higher education using UTAUT and structural equation modeling approaches. In Proceedings of the International Conference on Advanced Intelligent Systems and Informatics, Cairo, Egypt, 1-3 September 2018; pp. 469-480. 